\title{
Differential Regulation of Insulin-like Growth Factor Binding Protein Secretion from Human Decidual Cells by IGF-I, Insulin, and Relaxin
}

\author{
Kathryn M. Thrailkill, David R. Clemmons, “ Walker H. Busby, Jr.," and Stuart Handwerger \\ Departments of Pediatrics and Cell Biology, Duke University Medical Center, Durham, North Carolina 27710; and \\ Department of Medicine, *University of North Carolina School of Medicine, Chapel Hill, North Carolina 27599
}

\begin{abstract}
Several growth hormone-independent 25-31,000 kD insulinlike growth factor binding proteins (IGF-BPs) have been identified in plasma, extravascular fluids, and various cell-conditioned media. Cultured human decidual cells release three IGF-BPs with $24,000,30,000$, and $34,000 M_{\mathrm{r}}$. Using ligand blot analysis and an RIA for the 30,000- $M_{\mathrm{r}}$ form (IGF-BP-1), we examined the effects of IGF-I (10-1,000 $\mathrm{ng} / \mathrm{ml})$, insulin $(10-10,000 \mathrm{ng} / \mathrm{ml})$, and relaxin $(10-250 \mathrm{ng} / \mathrm{ml})$ on decidual cell IGF-BP release after $120 \mathrm{~h}$ of hormone exposure. IGF-I inhibited release of both IGF-BP-1 and the $24,000 M_{\mathrm{r}}$ form. Inhibition of IGF-BP-1 release was noted after $48 \mathrm{~h}$ of treatment and was progressive throughout the subsequent $120 \mathrm{~h}$. Insulin stimulated a fourfold increase in release of the 24,000 $M_{r}$ protein while inhibiting IGF-BP-1 release comparable to IGF-I. $\alpha$-IR3, a monoclonal antibody to the IGF-I receptor, blocked $\sim 33 \%$ of the IGF-I response but had no effect on insulin-mediated IGF-BP-1 inhibition. Relaxin stimulated a 2.4-fold increase in release of the $24,000-M_{r}$ form and a 16 fold increase in the $30,000-M_{\mathrm{r}}$ protein after $120 \mathrm{~h}$. Stimulation of the $30,000-M_{r}$ protein was inhibited by the addition of cycloheximide $(50 \mu \mathrm{g} / \mathrm{ml})$. Both IGF-I and insulin also blocked the relaxin-mediated increase in IGF-BP-1. These studies suggest that three structurally related proteins differentially regulate IGF-BP secretion possibly via activation of distinct receptor subtypes. (J. Clin. Invest. 1990. 86:878-883.) Key words: decidua • insulin-like growth factors • IGF-BPs • relaxin
\end{abstract}

\section{Introduction}

The insulin-like growth factors (IGFs) ${ }^{1}$ are ubiquitous peptides that diversely influence cellular proliferation and differentiation. These peptides circulate in plasma bound to specific carrier proteins (1-5). The IGF-binding proteins (IGF-BPs) serve not only to transport IGFs in the circulation $(5,6)$, but also to prolong their serum half-life $(4,6)$, modulate tissue specificity for IGF action $(4,7,8)$, and potentiate or neutralize various biologic actions of the IGFs (9-12).

Address correspondence and reprint requests to Dr. Kathryn Thrailkill, Duke University Medical Center, Box 3080, Durham, NC 27710. Received for publication 23 October 1989 and in revised form 2 April 1990.

1. Abbreviations used in this paper: IGF-BP, insulin-like growth factor binding protein.

J. Clin. Invest.

(C) The American Society for Clinical Investigation, Inc.

0021-9738/90/09/0878/06 \$2.00

Volume 86, September 1990, 878-883
Recent studies have shown that at least three structurally distinct forms of IGF-binding proteins exist. The first is a glycoprotein with an estimated molecular mass of 53,000 D (IGF-BP-3) (13-15). It forms a complex in blood with an acid labile protein. This $150,000-\mathrm{D}$ complex is thought to be the major carrier of IGF-I and IGF-II in the circulation. The other two proteins are not glycosylated, have lower mol wt estimates (31,000, IGF-BP-2 [16] and 25,000, IGF-BP-1 [17]), and have been purified from amniotic fluid or conditioned media of distinct cell types $(11,18-22)$. These proteins are minor carriers in blood and their binding capacity in other extravascular fluids relative to IGF-BP-3 is unknown. Several other forms of IGF-BP appear to be present in extravascular fluids (23-25). These have been defined by unique $M_{\mathrm{r}}$ estimates, failure to react with antisera specific for one of the known IGF-BPs, or a unique set of factors that control their secretion. They have not been structurally characterized.

At present, the factors regulating IGF-BP secretion are not completely defined. Plasma concentrations of IGF-BP-3 are growth hormone dependent while plasma concentrations of IGF-BP-1 and 2 are elevated in growth hormone-deficient states $(5,26)$. Tissue-specific regulation of binding protein secretion by various growth factors and steroid hormones has also been recently demonstrated in a few in vitro systems (27). Specifically, stimulation of IGF-BP secretion by IGF-I has been demonstrated in liver explants (28), myocytes (29), and human fibroblasts (21). Similarly, insulin has been shown to stimulate the release of IGF-BPs in myocytes but is inhibitory in Hep $G 2$ cultures $(29,30)$, suggesting that there may be cell type-specific patterns for regulation of IGF-BP secretion.

Recent studies have demonstrated that these binding proteins are secreted by human decidual tissue (31-33). We have previously demonstrated that human decidual cell cultures secrete three distinct IGF-BPs of 24,000, 30,000, and 34,000 $M_{\mathrm{r}}$ (34). The $30,000-M_{\mathrm{r}}$ form appears to be immunologically indistinguishable from the 25,272-D form (IGF-BP-1), first purified from amniotic fluid (BP-28 [20], placental protein 12 [32]), and later demonstrated in human endometrium $(33,35$, 36) and conditioned media of decidual explants (31), human hepatoma cells (37), and fibroblasts (21). In this study we have examined the effects of IGF-I, insulin, and relaxin, three structurally related proteins, on the release of IGF-BPs from human decidual cells. The results demonstrate differential regulation of decidual IGF-BP secretion by these three growth factors.

\section{Methods}

Cell preparation. Term placentas were obtained within $1 \mathrm{~h}$ of uncomplicated deliveries at either Duke University Medical Center or Durham County General Hospital, Durham, NC. In each instance, informed consent was obtained from the patient with permission of the Human Investigations Committee at Duke University Medical Center. 
Decidual tissue adherent to the chorion of the placental membranes was manually stripped away and rinsed in normal saline. The decidual tissue was then enzymatically digested in buffered RPMI 1640 culture media (Gibco Laboratories, Grand Island, NY) containing $0.1 \%$ Collagenase (Worthington Biochemical Corp., Freehold, NJ), 0.1\% Hyaluronidase (Sigma Chemical Co., St. Louis, MO), $0.1 \%$ trypsin inhibitor, and $\mathbf{0 . 0 0 0 5 \%}$ deoxyribonuclease I (Worthington Biochemical Corp.). The digestion mixture was filtered through a $150-\mu \mathrm{M}$ mesh nytex cloth (Swiss nylon monofilament; Tetko Inc., Elmsford, NY) and the resulting cell suspension was pelleted, washed, and layered onto linear density gradients of $40 \%$ Percoll (Sigma Chemical Co.). As previously demonstrated (38), an enriched fraction of prolactin-producing decidual cell sediments at a density of $1.017-1.044 \mathrm{~g} / \mathrm{ml}$ after centrifugation at $800 \mathrm{~g}$ for $20 \mathrm{~min}$. Viability of cells from this band was determined by trypan blue exclusion. 1 million cells/ml were then plated in collagen-coated (Vitrogen 100; Collagen Corp., Palo Alto, CA) 24-well tissue culture clusters (Costar Data Packaging Corp., Cambridge, MA) in RPMI 1640 medium supplemented with $10 \%$ fetal calf serum (Hyclone Laboratories, Logan, UT), $50 \mu \mathrm{g} / \mathrm{ml}$ gentamicin (Elkins-Sinn Inc., Cherry Hill, NJ), $25 \mu / \mathrm{ml}$ penicillin (Gibco Laboratories), $25 \mu / \mathrm{ml}$ streptomycin (Gibco Laboratories), and $5 \mu \mathrm{g} / \mathrm{ml} \mathrm{Am-}$ photericin B (Sigma Chemical Co.). Cells were allowed to attach to the matrix during a $48-\mathrm{h}$ incubation at $37^{\circ} \mathrm{C}$ in a humidified atmosphere of $95 \%$ air $/ 5 \% \mathrm{CO}_{2}$.

Experimental design. Cell cultures were maintained an additional $120 \mathrm{~h}$ in either control medium supplemented only with antibiotics, or media additionally supplemented with one or more of the following: (a) human recombinant IGF-I (10-1,000 ng/ml; Fujisawa Pharmaceutical Co., Osaka, Japan); (b) human semi-synthetic regular insulin (10-10,000 ng/ml, Novolin; Squibb Novo, Princeton, NJ); (c) porcine relaxin (National Institutes of Health, Bethesda, MD); $(d) \alpha$-IR $\mathbf{R}_{3}(100$ $\mathrm{nM}$ ), a monoclonal antibody to the type I IGF receptor, purified by sequential precipitation in 18 and $15 \%$ sodium sulfate (39) (provided by J. J. Van Wyk, University of North Carolina, Chapel Hill, NC); or (e) $1.0 \mu \mathrm{M}$ cycloheximide (Sigma Chemical Co.). Conditioned medium was sampled daily and exchanged completely with fresh media containing the appropriate treatments. IGF-BP concentrations in the media were assayed using an RIA specific for IGF-BP-1, the amniotic fluid binding protein, as previously described (40). As demonstrated by Hossenlopp, IGF-BP does not appreciably bind to collagen (41). The assay measurements represent the mean of duplicate determinations

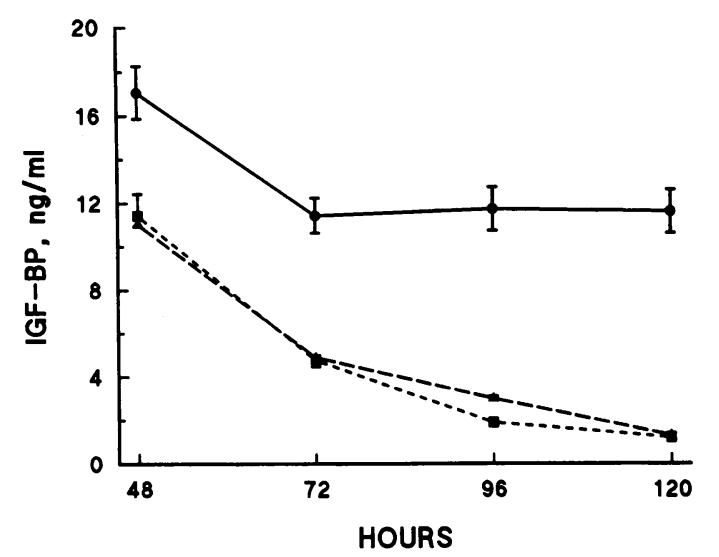

Figure 1. Inhibition of IGF-BP-1 release by IGF-I and insulin. Monolayer cultures of human decidual cells were exposed for $120 \mathrm{~h}$ to control media $(\bullet-\bullet)$ or media supplemented with $100 \mathrm{ng} / \mathrm{ml}$ IGF-I ( $(---\infty)$ or insulin $(\Delta---\Delta)$. Samples of conditioned media were collected from successive 24-h periods and assayed for IGF-BP. Each point represents the mean \pm SEM of triplicate cultures. At $48 \mathrm{~h}$, the $P$ value for the inhibition of IGF-BP-1 by IGF-I and insulin was $<0.01$ in each instance. At $72-120 \mathrm{~h}$, the $P$ value was $<0.001$ at each time.

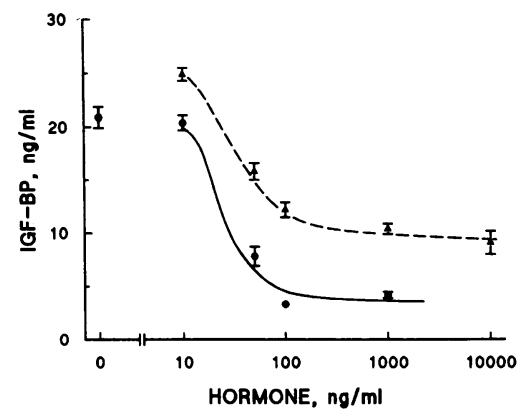

Figure 2. The dose-dependent effects of IGF-I and insulin on release of IGF-BP-1 from human decidual cells. Decidual cell cultures were exposed for $120 \mathrm{~h}$ to either IGF-I $(\bullet-\bullet)$ at concentrations ranging from 0 to 1,000 $\mathrm{ng} / \mathrm{ml}$ or insulin $(\mathbf{\Delta - - - \Delta )}$ at concentrations rang-

ing from 0 to $10,000 \mathrm{ng} / \mathrm{ml}$. Each point represents the mean \pm SEM of triplicate samples.

that were obtained from triplicate cultures. Each point therefore is the mean of six determinants.

After $120 \mathrm{~h}$ of hormone exposure, cells from selected experiments were gently harvested from the collagen matrix using collagenase, and the DNA content of harvested cells was determined fluorometrically using methods described by La Barca and Paigin (42).

Ligand blotting. A 20- $\mu$ l aliquot of conditioned media was added to Laemmli sample buffer (43) and heated to $60^{\circ} \mathrm{C}$ for $10 \mathrm{~min}$. Samples were then clarified by centrifugation and electrophoresed through a $12.5 \%$ SDS polyacrylamide gel. Separated proteins were transferred to nitrocellulose filters using a Janssen semi-dry electroblotter. The blots were then probed with $100,000 \mathrm{cpm} / \mathrm{cm}^{3}{ }^{125}$ I-IGF-I according to methods described by Hossenlopp (41). ${ }^{125}$ I-IGF-I (specific activity $150-250 \mu \mathrm{Ci} / \mu \mathrm{g}$ ) was prepared by a previously described method (44) and was a gift from L. Underwood (University of North Carolina, Chapel Hill, NC). Binding protein bands were then visualized by autoradiography following 3-5 d of exposure. Changes in band intensity were quantified by scanning densitometry using a Hoefer 350 scanning analysis program (Hoefer Scientific Instruments, San Francisco, CA). Band intensity changes were linear over the scanning range used in this study when pure IGF-BP-1 was used as a standard.

Statistics. All experimental variables were tested in triplicate and repeated using cell cultures from at least three different pregnancies. Multivariant statistical analysis was performed using the analysis of variance with planned orthagonal contrasts.

\section{Results}

In the experiment depicted in Fig. 1, decidual cells were exposed to either IGF-I $(100 \mathrm{ng} / \mathrm{ml})$ or insulin $(100 \mathrm{ng} / \mathrm{ml})$ for $120 \mathrm{~h}$. During the first 24-h period, IGF-BP-1 concentrations in the media of control and treated cultures were similar (data not shown). However, between 48 and $120 \mathrm{~h}$, cells exposed to either growth factor released significantly less IGF-BP-1 than control cultures. The degree of inhibition of IGF-BP-1 secretion increased over time.

The inhibitory effects of IGF-I and insulin were concentration dependent (Fig. 2). Half-maximal inhibition of IGFBP-1 was achieved at IGF-I, and insulin concentrations of 25 $\mathrm{ng} / \mathrm{ml}$ and maximal inhibition occurred at concentrations of $100 \mathrm{ng} / \mathrm{ml}$ or greater for both hormones. In this and in several other experiments insulin produced less absolute suppression of binding protein activity, though the pattern of IGF-BP inhibition by these two growth factors was indistinguishable.

At supraphysiologic concentrations (e.g., 1,000-10,000 $\mathrm{ng} / \mathrm{ml}$ ), insulin binds to the type I IGF receptor. In experiments designed to determine whether IGF-I and insulin share a common receptor pathway for inhibition of IGF-BP-1 secretion, we exposed decidual cultures to $\alpha-I_{3}$, a monoclonal 


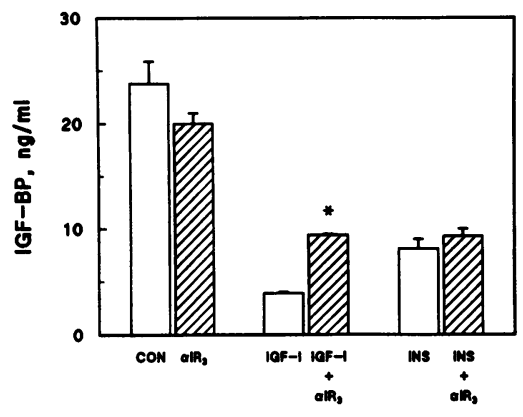
combination of $\alpha$-IR $\mathrm{R}_{3}$ with each growth factor. Each point represents the mean \pm SEM of triplicate cultures. ${ }^{*} P<0.01$.

antibody to the type I IGF receptor that inhibits IGF-I binding and type I IGF receptor mediated effects in other systems (39). As shown in Fig. 3, approximately one-third of the IGF-I effect could be inhibited by $\alpha$-IR $\mathrm{IR}_{3}$ exposure. In contrast, the combination of insulin plus $\alpha-\mathrm{IR}_{3}$ produced results that were not statistically different from those after treatment with insulin alone.

In contrast to IGF-I and insulin, relaxin $(100 \mathrm{ng} / \mathrm{ml})$ stimulated a marked increase in the release of IGF-BP-1 (Fig. 4). Relaxin-treated cultures released $125 \pm 4,369 \pm 25,1,340 \pm 64$, and $2,336 \pm 259 \%$ more IGF-BP than control cultures after 48-120 h of exposure, respectively. Relaxin-mediated effects were also dose dependent (Fig. 5). The half-maximal and maximal effective concentrations for stimulated release of IGF-BP were 25 and $100 \mathrm{ng} / \mathrm{ml}$, respectively. In addition, the basal and relaxin stimulated release of IGF-BP-1 was inhibited by exposure to cycloheximide (Fig. 6). This suggests that the increase in assayable IGF-BP-1 is primarily due to newly synthesized protein.

Comparing Figs. 4 and 1, significant variability in basal IGF-BP secretion was observed between different experiments. The etiology of this discrepancy is unclear though it is possible that some variability in the state of cellular differentiation or in the purity of a cell population existed among different cell preparations. Despite this discrepancy in basal secretion rates, effects of IGF-I, insulin, and relaxin were qualitatively reproducible in all experiments.

To exclude the possibility that the changes in IGF-BP-1 concentrations were the result of changes in cell number, we assayed the DNA content of cultures after $120 \mathrm{~h}$ of exposure to IGF-I, insulin, or relaxin $(100 \mathrm{ng} / \mathrm{ml})$. Total DNA/million

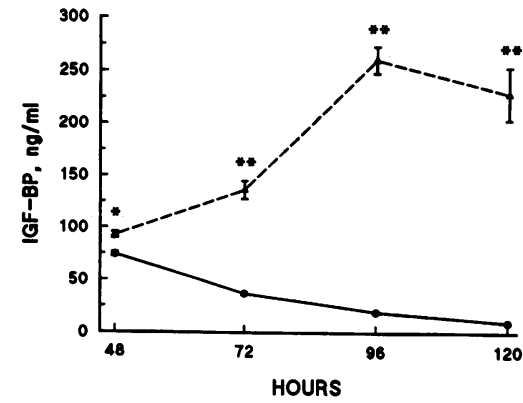

Figure 4. Stimulation of decidual IGF-BP-1 release by relaxin. Decidual cells in culture were exposed to porcine relaxin $(100 \mathrm{ng} / \mathrm{ml})$ $(\Delta---\Delta)$ for $120 \mathrm{~h}$. Samples of conditioned media from successive 24-h periods were assayed for IGF-BP-1. Each point represents the mean \pm SEM of triplicate cultures. This is compared with the IGF-BP-1 release from untreated control cultures $(\bullet-\bullet) .{ }^{*} P<0.01$; ${ }^{\ddagger} P<0.001$.

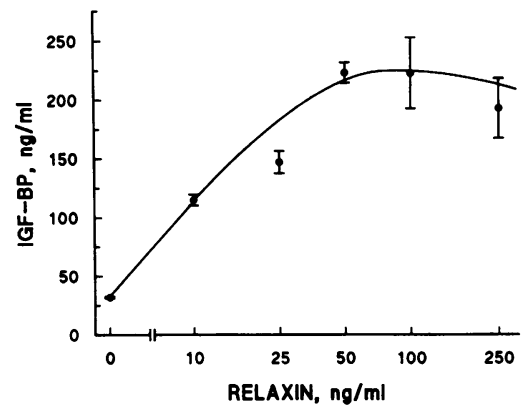

Figure 5. Concentration dependent increase in IGF-BP-1 release in response to relaxin. Relaxin concentrations ranging from $0-250$ $\mathrm{ng} / \mathrm{ml}$ were added to confluent decidual cultures over a 96-h period. Each point represents the mean \pm SEM of triplicate cultures assayed for IGF-BP-1 at $96 \mathrm{~h}$.

cells was not statistically different from control cultures (3.7 \pm 0.3 ; MEAN \pm SEM) after IGF-I (3.6 \pm 0.2$)$, insulin $(4.0 \pm 0.3)$, or relaxin $(4.4 \pm 0.1 \mu \mathrm{g})$ treatment.

To determine whether IGF-I, insulin, or relaxin also regulate release of the 24,000 and $34,000 M_{\mathrm{r}}$ IGF-BPs in a manner analogous to IGF-BP-1, conditioned media from treated cultures were compared by ligand blot analysis. A ligand blot of conditioned media from decidual cells exposed to $100 \mathrm{ng} / \mathrm{ml}$ IGF-I, insulin, or relaxin for $120 \mathrm{~h}$ is shown in Fig. 7. Three bands with $M_{\mathrm{r}}$ estimates of 24, 30, and 34,000 were detected in control medium (lane 1 ). The $30,000-M_{\mathrm{r}}$ band corresponds to IGF-BP-1 as determined by Western blotting. IGF-I (lane 2) inhibited release of both the 24- and $30-\mathrm{kD}$ binding proteins by 83 and $78 \%$, respectively (densitometric analysis). In contrast, insulin (lane 3) inhibited release of the $30,000 M_{\mathrm{r}}$ IGF-BP but stimulated a fourfold increase in intensity of the $24,000-M_{\mathrm{r}}$ protein band $(2,107 \pm 201-8,696 \pm 1,347 \mathrm{U})$. Neither IGF-I nor insulin appreciably affected release of the $34,000-M_{\mathrm{r}}$ form. Relaxin (lane 4) stimulated a 2.4-fold increase in the 24,000$M_{\mathrm{r}}$ form and a 16-fold increase in the $30,000-M_{\mathrm{r}}$ protein. It appeared to have little or no effect on the $34,000 M_{\mathrm{r}}$ IGF-BP.

We next determined if IGF-I or insulin could inhibit relaxin-stimulated release of IGF-BP-1. Cultures were exposed to the combination of IGF-I or insulin + relaxin. As shown in Fig. 8, relaxin induced a 2.5 -fold increase in IGF-BP-1 secretion. The addition of either IGF-I or insulin, however, completely blocked the stimulated release of binding protein by these cells.

\section{Discussion}

These experiments demonstrate that IGF-I suppresses secretion of both IGF-BP-1 and a $24,000-M_{\mathrm{r}}$ form of IGF-BP by

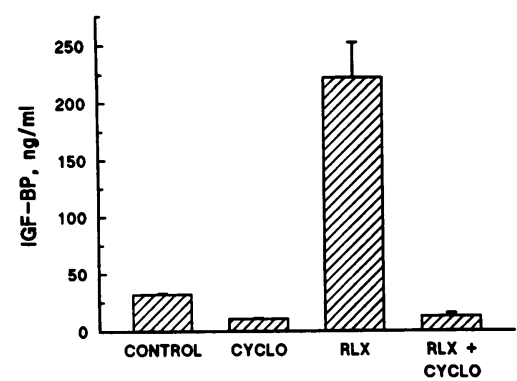

Figure 6. Inhibition of relaxin-mediated effects by cycloheximide. Decidual cultures exposed over a $96-\mathrm{h}$ period to either control medium, or medium supplemented with relaxin $(100$ $\mathrm{ng} / \mathrm{ml}$ ), cycloheximide $(50 \mu \mathrm{g} / \mathrm{ml})$, or the combination of the two were sampled daily and assayed for IGF-BP-1. Each point represents the mean \pm SEM of triplicate 96-h samples. Control vs. relaxin, $P<0.001$. 


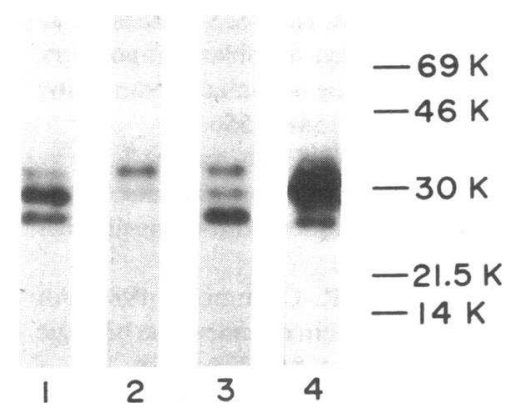

Figure 7. Differential regulation of the three forms of IGF-BP secreted by human decidual cells. $20-\mu l$ samples of $120 \mathrm{~h}$ conditioned media from decidual cultures exposed to IGF-I, insulin, or relaxin were electrophoresed through SDS polyacrylamide gels,

transferred to nitrocellulose filters, and probed with ${ }^{125}$ I-IGF-I $(100,000 \mathrm{cpm} / \mathrm{cc})$. Lane 1 shows the three forms of IGF-BP detected in control medium. Lanes 2, 3, and 4 show the differential effects of IGF-I, insulin, and relaxin, respectively, on the relative intensity of the 24,000- and 30,000- $M_{\mathrm{r}}$ bands. Defined molecular weight standards were run in a parallel lane.

human decidual cells in culture. Suppression of the 24- and $30,000-M_{\mathrm{r}}$ forms of IGF-BP by IGF-I is contrasted with IGF-I-mediated effects in other systems. For example, Clemmons et al. have demonstrated that IGF-I stimulates IGF-BP secretion from three distinct muscle cell types (29) and specifcally stimulates IGF-BP secretion by human fibroblasts (21). Binoux and Lasarre have shown that IGF-I stimulates the secretion of binding activity from liver explants (28). Similarly, induction of IGF-BP-2 and IGF-BP-3 secretion in serum following subcutaneous IGF-I infusion has been demonstrated in hypox and diabetic rat models and in normal man (45). In contrast, IGF-I and insulin have been shown to suppress IGFBP-1 secretion by Hep G2 cells in culture (30).

The reason for suppression of decidual IGF-BP-1 secretion by IGF-I is unclear. The IGF-BP RIA is a sensitive assay of both bound and unbound IGF-BP, and is unaffected by the presence of IGF-I in the media (40). Therefore, the effect is not mediated by changes in IGF-I saturation, which is confirmed by gel electrophoresis data. These findings, therefore, strongly support a cell type-specific response to IGF-I exposure.

The functional significance of suppression of IGF-BP-1 secretion in decidual cell physiology has not been clearly defined. IGF-BP-1 has high affinity for IGF-I and has been shown to enhance the cellular DNA synthetic response of fibroblasts and smooth muscle cells to IGF-I (11). If decidual IGF-BPs similarly potentiate in utero IGF-I effects on these cell types, suppression of IGF-BP-1 secretion by IGF-I may serve as a negative feedback control mechanism for modulating cellular growth in this system. Alternatively, decidual IGF-BP has been shown to inhibit ${ }^{125}$ I-IGF-I binding to both placental and endometrial receptors (46). In this situation, suppression of binding protein secretion by IGF-I would allow for a less complex and more direct growth factor-receptor interaction. We recognize, however, that when decidual cells are removed from their physiologic microenvironment, their response to various secretogogues may be altered from the response that occurs under in vivo conditions.

Insulin, like IGF-I, also inhibited release of IGF-BP-1. This inhibition does not appear to be the result of preferential degradation of IGF-BP-1 into the $24,000-M_{\mathrm{r}}$ form since the $24,000-M_{\mathrm{r}}$ protein is not detectable by Western blotting with the polyclonal antisera used in the IGF-BP-1 RIA (34). Insulin has been shown to have both stimulatory effects on IGF-BP secretion in myocytes (29) and inhibitory effects on IGF-BP secretion from cultures Hep G2 cells (30). Likewise, insulin appears to be a potent suppressor of IGF-BP secretion in vivo. In this system, however, insulin appears to be affecting decidual cell IGF-BP-1 secretion in a manner analogous to IGF-I.

Both IGF-I and insulin have a similar $\mathrm{IC}_{50}$ value for IGFBP-1 suppression (e.g., $25 \mathrm{ng} / \mathrm{ml}$ ). This insulin concentration is higher than would be necessary to activate insulin receptors, but lower than that necessary to bind to type I IGF receptors. This suggests that the insulin effect could be mediated through a distinct receptor subtype. Recently, Moxham et al. have described the existence of a unique receptor subtype composed of one $\alpha-\beta$ subunit from the type I IGF receptor and one from the insulin receptor (47). The insulin response noted above is consistent with a model whereby insulin effects are mediated via this unique receptor.

Significant inhibition of IGF-BP-1 secretion was not detected at IGF-I concentrations below $25 \mathrm{ng} / \mathrm{ml}$. It is possible that release of IGF-BPs may be attenuating the suppressive effects of IGF-I at lower concentrations. At higher concentrations, however, IGF-I consistently induced a greater degree of inhibition than the same concentration of insulin. $\alpha-\mathrm{IR}_{3}$ inhibited $\sim 1 / 3$ of the IGF-I response, suggesting that this portion of the total IGF-I response is mediated through the type I IGF receptor. The $\alpha-\mathrm{IR}_{3}$ concentration used in these experiments was fivefold greater than that shown to inhibit $83 \%$ of the specific binding of IGF-I to decidual type I receptors (48). Therefore, the receptor subtype mediating the remaining twothirds of the IGF-I response that is not inhibited by $\alpha$-IR $\mathrm{R}_{3}$ has not been determined.

Unlike IGF-I, insulin significantly stimulated release of the 24,000 $M_{\mathrm{r}}$ IGF-BP. Discordant hormonal regulation of multiple forms of IGF-BP from a single cell type has not previously been reported. This discordant response suggests that each species of binding protein may have distinct functional roles that need to be coordinated. Further studies are required to determine the range of cell types that respond to insulin in this manner.

The effects of relaxin on IGF-BP-1 secretion have not been previously described. Extraluteal localization of relaxin to human endometrial stromal cells and decidual cells has been noted (49-52), and the uterus is a major target tissue for relaxin effects on tissue growth and myometrial contractility (53-56). The present observations suggest that relaxin may also be involved in the regulation of IGF-BP secretion by uterine tissues through autocrine or paracrine mechanisms. In

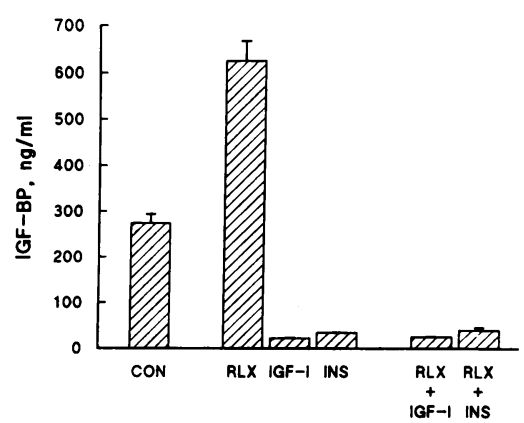

Figure 8. Effect of IGF-I and insulin on relaxin stimulated IGFBP-1 release. Monolayer cultures were exposed for $96 \mathrm{~h}$ to IGF-I, insulin, relaxin (100 $\mathrm{ng} / \mathrm{ml}$ each), IGF-I + relaxin, or insulin + relaxin. Triplicate cultures were assayed for IGF-BP-1 at $24 \mathrm{~h}$

intervals and the 96-h results are presented here as a mean \pm SEM. The effects of relaxin, IGF-I, and insulin were significantly different from control $(P<0.001$ in each instance). IGF-I and insulin inhibited the stimulation by relaxin $(P<0.001$ in each instance). 
contrast to IGF-I and insulin, relaxin caused a marked increase in the release of both the 24,000- and 30,000- $M_{\mathrm{r}}$ species. Whether such stimulation might potentiate or neutralize IGF-I action is unclear, but the observation opens up the possibility that relaxin could modulate tissue IGF responsiveness.

The potential interaction of relaxin with IGF-I or insulin receptors is less well characterized. Although relaxin has only $\sim 25 \%$ amino acid sequence homology with the insulin-like class of growth factors $(52,53)$, striking similarities of tertiary structure exist, potentially allowing for receptor cross-reactivity. Purified relaxin does not appreciably compete with binding of radiolabeled insulin to insulin receptors on IM-9 lymphocytes, leukocytes, or adipocytes (57), but the interaction of relaxin with the type I IGF receptor has not been determined. The striking stimulation seen in this study, however, in contrast to the inhibition of IGF-I and insulin, suggests that the signal allowing for this differential regulation of IGF-BP-1 secretion is transduced through a distinct receptor subtype.

We have previously demonstrated that activation of adenylate cyclase stimulates the secretion of IGF-BP-1 from the decidua (34). Interestingly, this intracellular signalling pathway has been implicated as a second messenger for relaxin in other systems (58-60). Since both IGF-I and insulin block both the relaxin- and cAMP-induced stimulation of decidual IGF-BP-1 synthesis, it is possible that cAMP may be mediating the relaxin signal.

In summary, a class of structurally homologous growth factors appears to play a unique role in the regulation of decidual IGF-BP secretion in vitro. The demonstration of localized in utero production of all three hormones suggests that this may represent a system of autocrine or paracrine regulatory control.

\section{Acknowledgments}

We thank Deloris Rogers and Kristen Carlton for technical assistance, Dr. Mineo Niwa and colleagues at the Fujisawa Pharmaceutical Co. (Osaka, Japan) for the gift of recombinant IGF-I, Dr. Steven Jacobs for the gift of hybridoma cells used to produce the monoclonal antibody $\alpha-\mathrm{IR}_{3}$, Dr. Judson Van Wyk for purification of $\alpha-\mathrm{IR}_{3}$, and Carol Dehamer and Gayle Kerr for secretarial assistance.

This work was supported by grants AG-02331, HD-15201, and HD-07190 of the National Institutes of Health.

\section{References}

1. Zapf, J., M. Waldvogel, and E. R. Froesch. 1975. Binding of nonsuppressible insulin-like activity to human serum: evidence for a carrier protein. Arch. Biochem. Biophys. 168:638-645.

2. Hintz, R. L., and F. Liu. 1977. Demonstration of specific plasma protein binding sites for somatomedin. J. Clin. Endocrinol. \& Metab. 45:988-995.

3. Hardouin, S., P. Hossenlopp, B. Segovia, G. Portolan, C. Lassarra, and M. Simoux. 1987. Heterogeneity of insulin-like growth factor binding proteins and relationships between structure and affinity. 1. Circulating forms in man. Eur. J. Biochem. 170:121-132.

4. Ooi, G. T., and A. C. Herington. 1988. The biological and structural characterization of specific serum binding proteins for the insulin-like growth factors. J. Endocrinol. 118:7-18.

5. Baxter, R. C., and J. L. Martin. 1989. Binding proteins for the insulin-like growth factors: structure, regulation and function. Prog. in Growth Factor Res. 1:49-68.

6. Hintz, R. L. 1984. Plasma forms of somatomedin and the binding protein phenomenon. Clin. in Endocrinol. Metab. 13:31-42.
7. Clemmons, D. R., R. G. Elgin, V. K. M. Han, S. J. Casella, A. J. D'Ercole, and J. J. Van Wyk. 1986. Cultured fibroblast monolayers secrete a protein that alters the cellular binding of somatomedin-C/insulin-like growth factor I. J. Clin. Invest. 77:1548-1556.

8. Clemmons, D. R., V. K. M. Han, R. G. Elgin, and A. J. D'Ercole. 1987. Alterations in the synthesis of a fibroblast surface associated $35 \mathrm{~K}$ protein modulates the binding of somatomedin-C/insulin-like growth factor I. Mol. Endocrinol. 1:339-347.

9. Elgin, R. G., W. H. Busby, and D. R. Clemmons. 1987. An insulin-like growth factor (IGF) binding protein enhances the biologic response to IGF-I. Proc. Natl. Acad. Sci. USA. 84:3254-3258.

10. Rutanen, E.-M., F. Pekonen, and T. Makinen. 1988. Soluble $34 \mathrm{~K}$ binding protein inhibits the binding of insulin-like growth factor I to its cell receptors in human secretory phase endometrium: evidence for autocrine/paracrine regulation of growth factor action. J. Clin. Endocrinol. Metab. 66:173-180.

11. Busby, W. H., Jr., D. G. Klapper, and D. R. Clemmons. 1988. Purification of a 31,000-Dalton insulin-like growth factor binding protein from human amniotic fluid. J. Biol. Chem. 263:14203-14210.

12. Ritvos, O., T. Ranta, J. Jalkanen, A.-M. Suikkari, L. R. Vout, H. Bohn, and E.-M. Rutanen. 1988. Insulin-like growth factor (IGF) binding protein from human decidua inhibits the binding and biological action of IGF-I in cultured choriocarcinoma cells. Endocrinology. 122:2150-2157.

13. Furlanetto, R. W. 1980 . The somatomedin $C$ binding protein: evidence for a heterologous subunit structure. J. Clin. Endocrinol. Metab. 51:12-19.

14. Baxter, R. C. 1988. Characterization of the acid-labile subunit of the growth hormone-dependent insulin-like growth factor binding protein complex. J. Clin. Endocrinol. Metab. 67:265-272.

15. Wood, W. I., G. Cachianes, W. J. Henzel, G. A. Winslow, S. A. Spencer, R. Hellmiss, J. L. Martin, and R. C. Baxter. 1988. Cloning and expression of the growth hormone-dependent insulin-like growth factor-binding protein. Mol. Endocrinol. 2:1176-1185.

16. Brown, A. L., L. Chiariotti, C. C. Orlowski, T. Mehlman, W. H. Burgess, E. J. Ackerman, C. B. Bruni, and M. M. Rechler. 1989. Nucleotide sequence and expression of a cDNA clone encoding a fetal rat binding protein for insulin-like growth factors. J. Biol. Chem. 264:5148-5154.

17. Brewer, M. T., G. L. Stetler, C. H. Squires, R. C. Thompson, W. H. Busby, and D. R. Clemmons. 1988. Cloning, characterization, and expression of a human insulin-like growth factor binding protein. Biochem. Biophys. Res. Commun. 152:1289-1297.

18. Drop, L. G., D. J. Kortleve, and H. J. Guyda. 1984. Isolation of a somatomedin-binding protein from preterm amniotic fluid: development of a radioimmunoassay. J. Clin. Endocrinol. Metab. 59:899-907.

19. D'Ercole, A. J., R. G. Elgin, S. L. S. Drop, and D. J. Kortleve. 1985. Somatomedin-C/insulin-like growth factor I-binding proteins in human amniotic fluid and in fetal and postnatal blood; evidence of immunological homology. J. Clin. Endocrinol. Metab. 61:612-617.

20. Baxter, R. G., J. L. Martin, and M. H. Wood. 1987. Two immunoreactive binding proteins for insulin-like growth factors in human amniotic fluid: relationship to fetal maturity. J. Clin. Endocrinol. Metab. 65:423-431.

21. Hill, D. J., C. Camacho-Hubner, P. Rashid, A. J. Strain, and D. R. Clemmons. 1989. Insulin-like growth factor (IGF)-binding protein release by human fetal fibroblasts: dependency on cell density and IGF peptides. J. Endocrinol. 122:87-98.

22. Lewitt, M. S., and R. C. Baxter. 1989. Regulation of growth hormone-independent insulin-like growth factor-binding protein (BP-28) in cultured human fetal liver explants. J. Clin. Endocrinol. Metab. 69:246-252.

23. Moses, A. C., A. J. Freinkel, B. B. Knowles, and D. P. Aden. 1983. Demonstration that a human hepatoma cell line produces a specific insulin-like growth factor carrier protein. J. Clin. Endocrinol. Metab. 56:1003-1008.

24. Bar, R. S., L. C. Harrison, R. C. Baxter, M. Boes, B. L. Dake, B Booth, and A. Cox. 1987. Production of IGF-binding proteins by vas- 
cular endothelial cells. Biochem. Biophys. Res. Commun. 148:734739.

25. Suikkari, A. M., J. Jalkanen, R. Koistinen, R. Butzow, O. Ritvos, T. Ranta, and M. Sappia. 1989. Human granulosa cells synthesized low molecular weight insulin like growth factor binding protein. Endocrinology. 124:1089-1090.

26. Binoux, M., P. Hossenlopp, S. Hardouin, D. Seurin, C. Lassarre, and M. Gourmelen. 1986. Somatomedin (insulin-like growth factors)-binding proteins: molecular forms and regulation. Horm. Res. (Basel). 24:141-151.

27. Schmid, C., M. Ernst, J. Zapf, and E. R. Froesch. 1989. Release of insulin-like growth factor carrier proteins by osteoblasts: stimulation by estradiol and growth hormone. Biochem. Biophys. Res. Commun. 160:788-794.

28. Binoux, M., and C. Lassarre. 1984. IGF stimulates the production of IGF binding protein (IGF-BP) by the liver. 7th International Congress of Endocrinology. 105:313a. (Abstr.)

29. McCusker, R. H., and D. R. Clemmons. 1988. Insulin-like growth factor binding protein secretion by muscle cells: effect of cellular differentiation and proliferation. J. Cell. Physiol. 137:505-512.

30. Conover, C. A., F. Liu, D. Powell, R. G. Rosenfeld, and R. L. Hintz. 1989. Insulin-like growth factor binding proteins from cultured human fibroblasts. J. Clin. Invest. 83:852-859.

31. Rutanen, E.-M., R. Koistinen, T. Wahlstrom, H. Bohn, T. Ranta, and M. Seppala. 1985. Synthesis of placental protein 12 by human decidua. Endocrinology. 116:1304-1309.

32. Koistinen, R., N. Kalkkinen, M. L. Huhtala, M. Seppala, H. Bohn, and E. M. Rutanen. 1986. Placental protein 12 is a decidual protein that binds somatomedin and has identical $\mathrm{N}$-terminal amino acid sequence with somatomedin-binding protein from human amniotic fluid. Endocrinology. 118:1375-1378.

33. Rutanen, E. M., R. Koistinen, and J. Sjoberg. 1986. Synthesis of placental protein 12 by human endometrium. Endocrinology. 118:1067-1071.

34. Clemmons, D. R., K. M. Thrailkill, S. Handwerger, and W. H. Busby. 1990. Three distinct forms of insulin-like growth factor binding proteins are released by decidual cells in culture. Endocrinology. 127:643-650.

35. Waites, G. T., R. F. L. James, and S. C. Bell. 1988. Immunohistological localization of the human endometrial secretory protein pregnancy-associated endometrial $\alpha_{1}$-globulin, an insulin-like growth factor-binding protein, during the menstrual cycle. J. Clin. Endocrinol. Metab. 67:1100-1103.

36. Bell, S. C., S. R. Patel, J. A. Jackson, and G. T. Waites. 1988. Major secretory protein of human decidualized endometrium in pregnancy is an insulin-like growth factor-binding protein. J. Endocrinol. 118:317-328.

37. Lee, Y.-L., R. L. Hintz, P. M. James, P. D. K. Lee, J. E. Shively, and D. R. Powell. 1988. Insulin-like growth factor (IGF) binding protein complementary deoxyribonucleic acid from human HEP G2 hepatoma cells: predicted protein sequence suggests an IGF binding domain different from those of the IGF-I and IGF-II receptors. Mol. Endocrinol. 2:404-411.

38. Markoff, E., P. Zeitler, S. Peleg, and S. Handwerger. 1983. Characterization of the synthesis and release of prolactin by an enriched fraction of human decidual cells. J. Clin. Endocrinol. Metab. 56:962-968.

39. Kull, F. C., Jr., S. Jacobs, Y.-E. Su, M. E. Svoboda, J. J. Van Wyk, and P. Cuatrecaces. 1983. Monoclonal antibodies to receptors for insulin and somatomedin-C. J. Biol. Chem. 258:6561-6566.

40. Busby, W. H., D. K. Snyder, and D. R. Clemmons. 1988. Radioimmunoassay of a 26,000-Dalton plasma insulin-like growth factor-binding protein: control by nutritional variables. J. Clin. Endocrinol. Metab. 67:1225-1230.

41. LaBarca, C., and K. Paigen. 1980. A simple rapid and sensitive DNA procedure. Anal. Biochem. 102:344-352.
42. Laemmll, U. K. 1970. Cleavage of structural protein during the assembly of the head bacteriophage T4. Nature (Lond.). 227:680-685.

43. Hossenlopp, P., D. Seurin, B. Segovia-Qwinson, S. Hardouin, and M. Binoux. 1986. Analysis of serum insulin-like growth factor binding proteins using Western blotting: use of the method for titration of the binding proteins and competitive binding studies. Anal. Biochem. 154:138-143.

44. D'Ercole, A. J., L. E. Underwood, J. J. Van Wyk, C. J. Decedue, and D. B. Foushee. 1976. Specificity, topography and ontogeny of the somatomedin $\mathrm{C}$ receptor in mammalian tissues. In Growth Hormone and Related Peptides. A. Pecile, and E. E. Muller, editors. American Elsevier/New York. 190-201.

45. Zapf, J., K. Binz, H. P. Guler, E. Scheiwiller, C. Schmid, and E. R. Froesch. 1988. Long-term S.C. infusion of recombinant human insulin-like growth factor I induces specific IGF serum carrier protein in hypox and diabetic rats and in normal man. Endocrinology. 122:219a. (Abstr.)

46. Pekonen, F., A.-M. Suikkari, T. Makinen, and E.-M. Rutanen. 1988. Different insulin-like growth factor binding species in human placenta and decidua. J. Clin. Endocrinol. Metab. 67:1250-1257.

47. Moxham, C. P., V. Duronio, and S. Jacobs. 1989. Insulin-like growth factor I receptor $\alpha$-subunit heterogeneity: evidence for hybrid tetramers composed of insulin-like growth factor I and insulin receptor heterodimers. J. Biol. Chem. 264:13238-13244.

48. Thrailkill, K. M., A. Golander, L. E. Underwood, and S. Handwerger. 1988. Insulin-like growth factor I stimulates the synthesis and release of prolactin from human decidual cells. Endocrinology. 123:2930-2934.

49. Koay, E. S. C., C. A. Bagnell, G. D. Bryant-Greenwood, S. B. Lord, A. C. Cruz, and L. H. Larkin. 1985. Immunocytochemical localization of relaxin in human decidua and placenta. J. Clin. Endocrinol. Metab. 60:859-863.

50. Bryant-Greenwood, G. D., M. C. P. Rees, and A. C. Turnbull. 1987. Immunohistochemical localization of relaxin, prolactin and prostaglandin synthase in human amnion, chorion and decidua. $J$. Endocrinol. 114:491-496.

51. Sakbun, V., E. S. C. Koay, and G. D. Bryant-Greenwood. 1987. Immunocytochemical localization of prolactin and relaxin C-peptide in human decidua and placenta. J. Clin. Endocrinol. Metab. 65:339343.

52. Von Koskull, H., P. Ammala, M. L. Huttala, and M. Seppala. 1989. Localization of insulin like growth factor binding protein and endometrial beta lactoglobulin in cultured decidual and chorionic villus cells. Hum. Reprod. 2:431-434.

53. MacLennan, A. H. 1981. Relaxin: a review. Aust. \& N. Z. J. Obstet. \& Gynaecol. 21:195-202.

54. Bryant-Greenwood, G. D. 1982. Relaxin as a new hormone. Endocr. Rev. 3:62-90.

55. Vasilenko, P., and J. P. Mead. 1987. Growth-promoting effects of relaxin and related compositional changes in the uterus, cervix, and vagina of the rat. Endocrinology. 120:1370-1376.

56. Koay, E. S. C., G. D. Bryant-Greenwood, S. Y. Yamamoto, and F. C. Greenwood. 1986. The human fetal membranes: a target tissue for relaxin. J. Clin. Endocrinol. Metab. 62:513-521.

57. Olefsky, J. M., M. Saekow, and R. L. Kroc. 1982. Potentiation of insulin binding and insulin action by purified porcine relaxin. Ann. NY. Acad. Sci. 380:200-215.

58. Hsu, C. J., S. M. McCormack, and B. M. Sanborn. 1985. The effect of relaxin on cyclic adenosine $3^{\prime}, 5^{\prime}$-Monophosphate concentrations in rat myometrial cells in culture. Endocrinology. 116:20292035.

59. Cronin, M. J., T. Malaska, C. Bakhit. 1987. Human relaxin increases cyclic-amp levels in cultured anterior pituitary cells. Biochem. Biophys. Res. Commun. 148:1246-1251.

60. Chen, G., J. R. Huang, and L. Tseng. 1988. The effect of relaxin on cyclic adenosine $3^{\prime}, 5^{\prime}$-monophosphate concentrations in human endometrial glandular epithelial cells. Biol. Reprod. 39:519-525. 